IZA DP No. 9933

Commuting Time and Sex Ratios in the US

Jose-Ignacio Gimenez-Nadal

Jose Alberto Molina

Jorge Velilla

May 2016 


\title{
Commuting Time and Sex Ratios in the US
}

\author{
Jose-Ignacio Gimenez-Nadal \\ University of Zaragoza \\ and CTUR
}

\section{Jose Alberto Molina}

University of Zaragoza

and IZA

Jorge Velilla

University of Zaragoza

\section{Discussion Paper No. 9933 \\ May 2016}

IZA

\author{
P.O. Box 7240 \\ 53072 Bonn \\ Germany
}

\author{
Phone: +49-228-3894-0 \\ Fax: +49-228-3894-180 \\ E-mail: iza@iza.org
}

\begin{abstract}
Any opinions expressed here are those of the author(s) and not those of IZA. Research published in this series may include views on policy, but the institute itself takes no institutional policy positions. The IZA research network is committed to the IZA Guiding Principles of Research Integrity.

The Institute for the Study of Labor (IZA) in Bonn is a local and virtual international research center and a place of communication between science, politics and business. IZA is an independent nonprofit organization supported by Deutsche Post Foundation. The center is associated with the University of Bonn and offers a stimulating research environment through its international network, workshops and conferences, data service, project support, research visits and doctoral program. IZA engages in (i) original and internationally competitive research in all fields of labor economics, (ii) development of policy concepts, and (iii) dissemination of research results and concepts to the interested public.
\end{abstract}

IZA Discussion Papers often represent preliminary work and are circulated to encourage discussion. Citation of such a paper should account for its provisional character. A revised version may be available directly from the author. 
IZA Discussion Paper No. 9933

May 2016

\section{ABSTRACT}

\section{Commuting Time and Sex Ratios in the US ${ }^{*}$}

In this paper, we analyze the relationship between potential worker supply, measured through sex ratios, and commuting times in the United States. Using the American Time Use Survey 2003-2014, we analyze the relationship between commuting times and sex ratios by state and age, and show that the proportion of males to females is negatively related to the commuting times of both male and female workers. Furthermore, this result applies to both private and public sector employees, but does not apply to the self-employed. To the extent that employers compensate their workers for their commutes, our results are important for employers. Given the negative effects of commuting on wellbeing and health, our results imply that individuals living in areas with higher sex ratios may have comparatively better health and well-being outcomes than workers living in areas with lower sex ratios.

JEL Classification: $\quad$ C21, J22, R41

Keywords: commuting time, sex ratio, ATUS, gender gap, United States

Corresponding author:

Jose-Ignacio Gimenez-Nadal

Faculty of Economic and Business

University of Zaragoza

C/ Gran Via 2

50005 Zaragoza

Spain

E-mail: ngimenez@unizar.es

* This paper has benefited from funding from the Spanish Ministry of Economics (Project ECO201234828). 


\section{Introduction}

In this paper, we analyze the relationship between potential worker supply, measured through sex ratios (defined as the number of male individuals for each female) and commuting times in the United States. Commuting represents a significant part of the daily time devoted to market activities by workers (Kenworthy and Laube, 1999; Gimenez-Nadal and Molina, 2016), and is one of the activities that provides the lowest “instant enjoyment” to individuals (Kahneman and Krueger, 2006). In addition, commuting has associated psychological, health, wellbeing, efficiency and work-search costs, (Kahneman et al., 2004; Roberts et al 2011; Novaco and Gonzalez, 2009; Ross and Zenou, 2006; Gimenez-Nadal, Molina and Velilla, 2016), and individuals devote a significant, and increasing, part of their total market/work time to it (Kirby and LeSage, 2009; McKeinze and Rapino, 2009). There is a vast literature suggesting that current commuting trips, measured through time or distance, are significantly longer than the optimal ones (Hamilton, 1982; White, 1986; Zax, 1991; Holzer et al., 1994; Crane, 1996; Buliung and Kanaroglou, 2002; and Manning, 2003), with its associated costs also being higher than they should be. Thus, commuting behavior is an interesting topic of research in economics, and it may be useful, not only for researchers and policy makers, but for workers and employers in their daily life.

Commuting and gender have been analyzed in the past, and a general conclusion obtained from prior research is that men and women have different commuting behavior, as men devote significantly more time to commuting than do women (Kain, 1962; Schulz and Gilbert, 1996; Doyle and Taylor, 2000; Hamilton and Jenkins, 2000; Crane, 2007; Mok, 2007; Sandow and Westin, 2010; Sánchez de Madariaga, 2013; Gimenez-Nadal and Molina, 2016). If women have the shortest commutes, and a shorter commute has been found to be related with fewer labor opportunities (MacDonald, 1999; Rapino, 2008; Wheatley, 2013), then it may be considered that the labor supply of women is different from that of men. This gap in commuting times is said to be driven by different preferences in the degree of specialization of jobs: men tend to be more specialized and, then, they must search in a narrower range and assume potentially longer commutes (Hanson and Johnston, 1985; Hanson and Pratt, 1995). Another potential explanation for gender differences in commuting behavior is the Household Responsibilities Hypothesis (HRH), which contends that a meaningful part of those commuting (and thus labor) differences can be due to differential assignments of the household activities within 
couples (see Gimenez-Nadal and Molina (2016) for a review and analysis of this hypothesis).

While commuting has been heavily analyzed in several fields, such as labor, urban economics, and transport economics (see Ma and Banister, 2006, for a chronological review), to the best of our knowledge the relationship between one indicator of potential labor supply, that is the sex ratio, and the commuting behavior of workers has not been studied. The analysis of the relationship between commuting behavior and sex ratios is of interest because it can explain, to some extent, a wide range of family and labor outcomes within the household. In this sense, household collective models take couples as a unit but differentiate between the 'husband' and the 'wife' within the couple. This differentiation is based on an intra-household decision problem that depends on wages, uses of time (leisure, market work, household production) and distributional factors (Browning et al., 2011). Sex ratios have been used as a measure of these distributional factors that potentially affect intra-household decisions, and thus affect commuting, family responsibilities, and other time-use characteristics.

Furthermore, the sex ratios can be interpreted as a measure of the relative supply of work by gender. Kanter (1977) summarizes the potential effect of sex ratios on the dynamic aspects of labor, including differences in the supply of work; Dreher (2003) finds that sex ratios are strongly related to gender labor attributes, such as female leadership, and to the female supply of work). Since commuting is a market-work activity, it is interesting to analyze the relationship between the relative supply of work by gender with the time devoted to commuting by male and female individuals (recently, GimenezNadal and Molina, 2014, find a 'U-shaped' relationship between commuting and work times, as an approach to the supply of work; Koslowsky et al., 1995, and Gutiérrez-iPuigarnau and van Ommeren, 2010, also find significant relationships between commuting and the supply of paid work).

Against this background, we empirically analyze the relationship between commuting times and sex ratios, using the American Time Use Survey (ATUS) database for the years 2003 to 2014, to measure the commuting time of workers, and sex ratios from the Integrated Public Use Microdata Series (IPUMS) database, and merge them according to the state of residence and year of the survey. Our results suggest that there is a negative relationship between sex ratios and commuting time for both men and 
women, which is mainly concentrated in private and public sector employees, and commuters by private vehicle. In particular, one additional male for each 100 female individuals (i.e., an increase of one percentage point) is associated with a decrease of around one percent in the commuting times of male and female public sector workers (around half a minute), and 0.6 percent (20 seconds) for private sector employees. This relationship may indicate that as men relatively increase in comparison to women, more men need work and thus consider accessing jobs traditionally occupied by women, which are also characterized by lower commutes due to women's household responsibilities. Furthermore, as the proportion of males increases, females have fewer available jobs, and to the extent that full-time jobs tend to be occupied by men, women occupy part-time jobs, or 'worse' and less-specialized jobs that men tend to refuse, along with shorter commutes and lower wages.

Our contribution to the literature is twofold. We first shed light on the relationship between commuting and the labor supply, measured through the sex ratio, (which, to the best of our knowledge, has not yet been studied). Our empirical analysis relies on OLS linear models with the most current US data available. Second, it may be important for future transportation planning, regarding the varied demands of transportation modes for workers. For instance, it could be that the transportation demands of workers are different depending on the sex ratio of the area of residence, as certain workers are more likely than others to use public transport (Schulz and Gilbert, 1996; Doyle and Taylor, 2000; Hamilton and Jenkins, 2000; Sánchez de Madariaga, 2013).

The remainder of the paper is organized as follows. Section 2 describes the data and variables, Section 3 presents the empirical analysis, and Section 4 concludes.

\section{Data and variables}

We use the data from the American Time Use Survey (ATUS) for the years 2003 to 2014. This survey is conducted annually by the US Bureau of Labor Statistics. The database contains information about commuting times (“commuting to/from work", coded as “180501”). (More information can be found at www.bls.bov/tus/.) We also make use of the IPUMS database for information on sex ratios, which are then merged with the ATUS data by age and state of residence of the respondent, and year of the survey 
(https://www.ipums.org), to arrive at the number of men for each woman. The advantage of diary-based surveys over stylized question-based surveys is that the former provide us with a less biased measure of commuting times (Juster and Stafford, 1985; Robinson, 1985; Bianchi et al., 2000; Bonke, 2005; Kan, 2008).

Also, although we focus on commuting times, it is important to acknowledge that alternative analyses using commuting distances may yield different results. Rietveld et al. (1999) argue that, in the measurement of travel distances (by car), actual distances are not normally known and information on the "shortest" route is used instead. Furthermore, when actual travel times are measured using transport surveys, commuters tend to include ancillary activities such as walking to the final destination, and while shorter commuting times tend to be underestimated, relatively longer commuting times tend to be overestimated (Bovy and Stern, 1990). Since we have information for all daily activities of the respondents, we can remove that kind of ancillary activity from our definition of commuting activity and thus our measure of commuting time has a smaller measurement error in comparison with one derived from transport surveys.

We restrict our sample to employed individuals aged between 16 and 65 who devote more than 60 minutes to work on the diary day, and whose information about the transport mode is available. This leaves us with 19,517 $(17,742)$ male (female) individuals, of which 13,797 $(12,538)$ commute by private vehicle (car, truck, or motorcycle), 2,441 $(3,299)$ by public transport, and $2,255(1,015)$ are what we call active commuters (walking or by bicycle). Table 1 shows summary statistics of our variables, by gender. We also include Kruskal-Wallis p-values for the comparisons between male and female. We observe that male workers devote, on average, 48 daily minutes to commuting, ten minutes more than women, which is consistent with the known commuting gap favoring male workers (Sandow and Westin, 2010; Gimenez-Nadal and Molina, 2016). This gap in commuting times is considered to be driven by different preferences in the degree of specialization of jobs: men tend to prefer more specialized jobs, and thus they must search in a narrow range and potentially assume longer commutes (Hanson and Johnston, 1985; Hanson and Pratt, 1995). Another, complementary, explanation relies on time-use theory and the fact that women devote more time to childcare, homework, and home production. These household responsibilities have a significant effect on women's time schedules, but not on those of men (Gimenez-Nadal and Molina, 2016), and thus women devote less time to commuting because they must devote more time to family activities. This theory 
complements the previous one because women, in this context, must accept jobs nearer to home,and the degree of specialization of such jobs plays a secondary role.

The sex ratio measures the number of male individuals for each female, taken, by age, state, and year, from the IPUMS database (https://www.ipums.org) and then merged with the ATUS database by the correspondent's age, state of residence, and year of the survey. The mean values of the sex ratios are 0.955 for male and 0.954 for female, with this difference not being significant at standard levels. However, sex ratios and commuting are significantly correlated, with a linear correlation index of -0.031 . When we look at male and female workers separately, we find a correlation of -0.027 for men and -0.040 for women. Figure 1 shows the previous relationship, where we average commuting times for each value of sex ratio. For instance, for a sex ratio value of 0.95 , we consider all similar observations and average the commuting time. We can see that the linear and polynomial trends barely differ, and both confirm the negative relationship of the variables, doubly so in the case of women.

\section{Econometric analysis and results}

We estimate OLS regressions on the logarithm of commuting times (plus 1, to avoid problems with 0 commuting times). The statistical model is as follows: for a given individual ' $i$ ', let $C_{i}$ be the reported commuting time, $S R_{i}$ be the sex ratio applicable to respondent ' $i$ ', $X_{i}$ be a set of socio-demographic variables, and $\varepsilon_{i}$ unmeasured factors. We estimate:

$$
\log \left(C_{i}\right)=\beta_{0}+\beta_{1} \log \left(S R_{i}\right)+\boldsymbol{\beta}_{2} \boldsymbol{X}_{i}+\varepsilon_{i}
$$

by gender to show the possible different relationship between the sex ratio and the commute, for men and women. We make use of a log-log specification to make inferences in percentage points. We cluster the standard errors using the Metropolitan Statistical Area (MSA) and the MSA size (population) to take into account that commuting times of individuals living in the same areas may be related, and that factors such as weather conditions may affect the time devoted to commuting. ${ }^{1}$ The ATUS coded the population

\footnotetext{
${ }^{1}$ The MSA variable reports the metropolitan area in which a household is located, and areas are counties or groups of counties centering on a substantial urban area. While the Census Bureau's terminology for metropolitan areas and the classification of specific areas changes over time, the general concept is consistent: a metropolitan area consists of a
} 
size of the MSAs as follows: 2) 100,000-249,999 inhabitants, 3) 250,000-499,999 inhabitants, 4) 500,000- 999,999 inhabitants, 5) 1,000,000-2,499,999 inhabitants, 6) 2,500,000-4,999,999 inhabitants, and 7) 5,000,000+ inhabitants. We also include occupation, industry, and year fixed effects.

Although most theoretical models assume workers are homogeneous, there may be industries or occupations where it is more difficult to hypothesize that male and female workers have the same characteristics. Hanson and Johnston (1985) and Hanson and Pratt (1995) find differences in commuting by occupation. Thus, we need to take into account the industry and occupation fixed effects of workers. We use the classification of the ATUS, based on the 2002/2010 Census Occupation Classification and the 2002/2007 Census Industry Classification. The ATUS aggregates these classifications in 14 industries (Agriculture, forestry, fishing and hunting; Mining; Construction; Manufacturing; Wholesale and retail trade; Transportation and utilities; Information; Financial activities; Professional and business services; Educational and health services; Leisure and hospitality; Other services; Public administration; and Armed Forces) and 11 occupations (Management, business, and financial; Professional and related; Service; Sales and related; Office and administrative support; Farming, fishing, and forestry; Construction and extraction; Installation, maintenance, and repair; Production; Transportation and materials moving; and Armed Forces) categories.

Vector $X_{i}$ includes socio-demographic variables that may affect commuting times, such as education (Primary, Secondary, and University education), living in couple, partner’s labor status, being white and American (all the former are dummy variables), number of children, number of weekly working hours, and household income. All of these variables are significantly different at standard levels across gender. According to Table 1 , there are more male workers with primary and secondary education level, in contrast with a higher number of female workers with University education. There are more male workers who live in couple than female workers, but there are more female workers whose partner also works. Both results mean a higher proportion of households in which the husband works but the wife does not. Male workers tend to have more children than female ones, which may be directly related to the previous result. Furthermore, men tend

large population center and adjacent communities that have a high degree of economic and social interaction. Metropolitan areas often cross state lines. 
to work more weekly hours than women, and also earn more, in line with the known gender wage gap (Weichselbaumer and Winter-Ebmer, 2005). ${ }^{2}$

Table 2 shows the results of estimating Equation (1) for the whole sample. Columns 1, 2, and 3 refer to men, and Columns 4, 5, and 6 refer to women (who commute by private vehicle, actively, or by public transport, respectively). We find a negative and significant relationship between commutes in private vehicles and sex ratios. If the sex ratio increases by $1 \%$, average commuting time in private modes of transport (e.g., car, motorbike...) decrease by $0.507 \%$ for men and by $0.595 \%$ for women. This relationship may indicate that as men relatively increase in comparison to women, more men need a job and thus consider accessing jobs traditionally occupied by women. Shorter commutes may also be due to women's household responsibilities. Furthermore, as men relatively increase in comparison to women, women have fewer available jobs and, to the extent that full-time jobs tend to be occupied by men, women occupy part-time jobs or 'worse' and less-specialized jobs that men tend to refuse, also characterized by shorter commuting given their lower wages.

Other factors affecting the time devoted to commuting by workers in the US are the presence of a partner, the normal hours of weekly work, and the household income, all of which have positive relationships with commuting. Since higher wages are attained in specialized jobs, individuals tend to be willing to devote more time to commuting to jobs with higher wages, or with longer working schedules; and couples usually have more expenses than single individuals, with the latter relationships being in line with the expected ones. On the other hand, if the partner is working, being white and being American are bth negatively related to the time devoted to commuting. The former result is clear since, when both members of a family have a job, the family has two sources of income and thus a lesser income is required from each source, with a subsequent decrease in commuting, according to the relationship described above. The results for race and nationality are consistent with the Spatial Mismatch Hypothesis analyzed in previous studies (Kain, 1968), which argues that commuting depends on residential segregation,

\footnotetext{
${ }^{2}$ We also have information on total household income, and the survey allows us to consider the following income levels: 0, 2,500, 6,250, 8,750, 11,250, 13,750, 17,500, 22,500, 27,500, 32,500, 37,500, 45,000, 55,000, 67,500, 87,500, 125,000 and $160,000+$.
} 
with immigrants and black individuals being those who traditionally tend to live in the places with the worst labor conditions and travel communications.

In Table 3, we repeat the estimations of (1) for private and public sector employees, and the self-employed who commute by private mode of transport, respectively, by gender. We find that, in general, the previous results are confirmed for employees, but not for the self-employed. This may be due to the different nature of the self-employment labor market, relative to its employment counterpart (van Ommeren and van der Straaten, 2008, Gimenez-Nadal, Molina and Velilla, 2016).

Thus, we can conclude that there appears to be a negative relationship between sex ratios and commuting times that is mainly driven by private or public sector workers commuting by private vehicle modes of transport, but not for the self-employed. We argue that this negative relationship may be mainly driven by supply of workers, the degree of specialization of those workers, the importance of household responsibilities for women, and the causal interactions of the three latter aspects.

Finally, to test for the consistency of our results, we apply a "placebo test” (Bertrand et al., 2002; Helland and Tabarrok, 2004) in which we repeat our empirical analysis but we randomly match individuals with possible values of the variable sex ratio, in order to check whether our results are sensitive to the correct inclusion of this variable. ${ }^{3}$ In order to do so, we do not match individuals living in a State with the sex ratio of that State. That is, for those individuals living in Wyoming, we match the values of sex ratios that do not pertain to Wyoming. These 'placebo tests' are presented in the Appendix (Table A1), and we consider regressions where we obtain statistically significant coefficients of sex ratios (male and female workers commuting by private transport, Columns (1) and (2), and male and female workers in the private and public sectors, Columns (3) to (6)). We can observe that the parameter associated with 'placebo sex ratios' is not significantly different than 0 in all the cases that have been analyzed. Our results indicate that the effect of sex ratios on commuting time is not originated by third, unmeasured factors related to both commuting time and sex ratios, leaving aside migration flows.

\footnotetext{
${ }^{3}$ The 'Placebo Laws test' is usually used to test whether a law has a true impact, or whether its effect could be due to other scenarios or characteristics than the law itself. It consists of introducing a fictional variable in a model to simulate its effect in a scenario where the characteristic that such a variable represents is absent (e.g., a new current law against crime in a model based on non-current data, to check the real impact of the law).
} 


\section{Conclusions}

This paper analyses the relationship between the supply of workers, measured through sex ratios, and commuting, using the ATUS 2003-2014. We show that this relationship is negative and applies to employees who commute by car or motorcycle. Furthermore, our results suggest that self-employment constitutes a different labor- market scenario. Our analysis has the limitation of being based on cross-sectional data, which requires that we deal with problems of unobserved heterogeneity. We find that commuting behavior depends strongly on random and stochastic facts, and thus the accuracy of the model is not as strong as it could be, as argued by van Ommeren and van der Straaten (2008).

Our main result allows us to make certain recommendations for employees. Our results show that sex ratios have no effect on the commuting patterns of those individuals who commute actively or by public transport. Furthermore, active commuting is desirable, when and where possible, not only for the monetary savings derived, but also for the improvements in satisfaction and health (Martin et al., 2014). To the extent that the relationship between sex ratios and commuting is due to supply-side differences by gender, along with the effect of the differential household responsibilities of women, improvements in gender equality could contribute to the disappearance of this supplyside effect.

Because commuting has negative effects on well-being, it could be argued from our results that the higher the sex ratio, the shorter the commute and thus, the less negative costs to well-being. However, it has been argued that sex ratios may be related to household responsibilities, which can also have negative effects on women's well-being. In this sense, Lennon (1994) finds that both employed and homemaker wives have psychological well-being costs derived from housework responsibilities, McLanahan and Adams (1987) and Gjerdingen et al. (2001) find that labor-force participation and household responsibilities have a negative effect on women's satisfaction, and Baker et al. (2005) find that childcare responsibilities have a significant effect on the labor supply of women, with maternity leading to worse health and the election of a non-desirable job. Following Chiappori’s cooperative household models (see Bourguignon and Chiappori, 1992, for an introduction, and Browning et al., 2011, for an extensive approach), the key role is to maximize the satisfaction of the household (i.e., the 'husband' and the 'wife') 
as a unit, taking into account all variables, including all benefits and costs derived from commuting, housework, and paid work as a whole.

The analysis of commuting relies on two measures: time and distance. A recent review of the different measures and indices of commuting can be found in Kanaroglou et al. (2015). There is evidence suggesting that commuting times are a more accurate measurement of commuting behavior because, first, distance is not what matters in long commutes by private vehicle (Rietveld et al., 1999) and, second, commuting times and distances depend on the transport mode, and it is time that has a greater impact on the associated satisfaction or well-being costs (Gimenez-Nadal and Molina, 2016). But despite that we are using commuting time, we can only a partial view, due to the lack of data on distance, and thus we cannot know the consequences for our analysis if such data were to be included.

\section{REFERENCES}

Aguiar, M. and E. Hurst (2007). "Measuring trends in leisure: The allocation of time over five decades," Quarterly of Journal Economics 122, 969-1007.

Baker, M., Gruber, J., and K. Milligan (2005). Universal childcare, maternal labor supply, and family well-being (No. w11832). National Bureau of Economic Research.

Bertrand, M., Duflo, E. and S. Mullainathan (2002). How much should we trust differences-indifferences estimates? (No. w8841). National Bureau of Economic Research.

Bianchi, S.M., Milkie, M.A., Sayer, L.C., and J.P. Robinson (2000). "Is anyone doing the housework? Trends in the gender division of household labor," Social forces 79, 191-228.

Bonke, J. (2005). "Paid work and unpaid work: Diary information versus questionnaire information,” Social Indicators Research 70 349-368.

Bourguignon, F., and P.A. Chiappori (1992). "Collective models of household behavior: An introduction,” European Economic Review 36 355-364.

Bovy P.H.L. and E. Stern (1990). "Route Choice: Wayfinding in Transport,” Networks. Studies in Operational Regional Science, 9.

Browning, M., Chiappori, P.A., and Y. Weiss (2011). Family economics. Tel Aviv University, unpublished textbook manuscript.

Buliung, R.N., and P.S. Kanaroglou (2002). “Commute minimization in the Greater Toronto area: applying a modified excess commute,” Journal of Transport Geography, 10, 177-186.

Crane, R. (1996). "The influence of uncertain job location on urban form and the journey to work,” Journal of Urban Economics, 39, 32-356. 
Crane, R. (2007). "Is there a quiet revolution in women's travel? Revisiting the gap in commuting,” Journal of the American Planning Association 73, 298-316.

Doyle, D. and B. Taylor, (2000). "Variation in metropolitan travel behavior by sex and ethnicity," in Travel patterns of people of color: Final report (pp. 181-214), prepared by Battelle, Columbus, Ohio. Washington DC: US Department of Transportation, Federal Highway Administration.

Dreher, G. F. (2003). "Breaking the glass ceiling: The effects of sex ratios and work-life programs on female leadership at the top," Human Relations 56, 541-562.

Gimenez-Nadal, J.I., and J.A. Molina (2014). "Commuting time and labor supply in the Netherlands,” Journal of Transport Economics and Policy 48, 409-426.

Gimenez-Nadal, J.I. and J.A. Molina (2016). “Commuting Time and Household Responsibilities: Evidence using Propensity Score Matching,” Journal of Regional Science 56, 332-359.

Gimenez-Nadal, J.I., Molina, J.A., and J. Velilla (2016). "Spatial distribution of US employment in an urban wage-efficiency setting,” Boston College Economic WP no. 890.

Gimenez-Nadal, J.I. and A. Sevilla, (2012). “Trends in time allocation: a cross-country analysis,” European Economic Review 56, 1338-1359.

Gjerdingen, D., McGovern, P., Bekker, M., Lundberg, U., and T. Willemsen (2001). "Women's work roles and their impact on health, well-being, and career: comparisons between the United States, Sweden, and The Netherlands," Women \& Health 31, 1-20.

Gutiérrez-i-Puigarnau, E. and J.N. van Ommeren, (2010). "Labor supply and commuting," Journal of Urban Economics 68, 82-89.

Hamilton, B.W. (1982). “Wasteful commuting,” The Journal of Political Economy 90 1035-1053.

Hamilton, K. and L. Jenkins, (2000). “A gender audit for public transport: A new policy tool in the tackling of social exclusion,” Urban Studies 37, 1793-1800.

Hanson, S., and J. Johnston (1985). "Gender differences in work trip lengths: Implications and explanations,” Urban Geography 6, 193-219.

Hanson, S., and G. Pratt (1995). Gender work and space. International studies of Women and Place. London: Routledge.

Helland, E. and A. Tabarrok (2004). "Using placebo laws to test" more guns, less crime"," Advances in Economic Analysis \& Policy 4(1).

Holzer, H.J., Ihlanfeldt, K.R., and D.L. Sjoquist (1994). "Work, search, and travel among white and black youth,” Journal of Urban Economics, 35, 320-345.

Juster, F.T. and F.P. Stafford (1985). Time, goods, and well-being.

Kahneman, D. and A.B. Krueger (2006). "Developments in the Measurement of Subjective WellBeing,” Journal of Economic Perspectives 20, 3-24.

Kahneman, D., A.B. Krueger, D. Schkade, N. Schwarz and A. Stone (2004). “A Survey Method for Characterizing Daily Life Experience: The Day Reconstruction Method,” Science 3, 1776-1780.

Kain, J.F. (1962). “The journey-to-work as a determinant of residential location,” Papers and Proceedings of the Regional Science Association 9, 137-160. 
Kain, J.F (1968). "Housing segregation, negro employment, and metropolitan decentralization,” The Quarterly of Journal Economics 175-197.

Kan, M.Y. (2008). "Measuring housework participation: the gap between "stylised” questionnaire estimates and diary-based estimates," Social Indicators Research 86, 381-400.

Kanaroglou, P.S., Higgins, C.D. and T.A. Chowdhury (2015). Excess commuting: a critical review and comparative analysis of concepts, indices, and policy implications," Journal of Transport Geography 44, 13-23.

Kanter, R. M. (1977). "Some effects of proportions on group life: Skewed sex ratios and responses to token women,” American journal of Sociology, 965-990.

Kenworthy, J.R. and F.B. Laube (1999). "Patterns of automobile dependence in cities: an international overview of key physical and economic dimension with some implications for urban policy,” Transportation Research Part A: Policy and Practice 33, 691-723.

Kirby, D.K. and J.P. LeSage (2009). "Changes in commuting to work times over the 1990 to 2000 period,” Regional Science and Urban Economics 39, 460-471.

Koslowsky, M., Kluger, A.V. and M. Reich (1995). Commuting stress: Causes, effects, and methods of coping. New York: Plenum Press.

Lennon, M.C. (1994). "Women, work, and well-being: The importance of work conditions," Journal of Health and Social Behavior 235-247.

Ma, K.R. \& D. Banister (2006). “Excess commuting: a critical review,” Transport Reviews, 26, 749-767.

MacDonald, H.I. (1999). “Women’s employment and commuting: Explaining the links,” Journal of Planning Literature 13, 267-283.

Manning, A. (2003). “The real thin theory: monopsony in modern labour markets," Labour Economics 10, 105-131.

Martin, A., Goryakin, Y. and M. Suhrcke (2014). "Does active commuting improve psychological wellbeing? Longitudinal evidence from eighteen waves of the British Household Panel Survey,” Preventive Medicine 69, 296-303.

McKenzie, B., and M. Rapino (2009). “Commuting in the United Stated: 2009,” U.S. Department of Commerce, Economics and Statistics Administration, U.S. CENSUS BUREAU.

McLanahan, S., and J. Adams (1987). "Parenthood and psychological well-being,” Annual review of sociology 237-257.

Mok, D. (2007). "Do two-earner household base their choice of residential location on both incomes?,” Urban Studies 44, 723-750.

Novaco, R.W., and O.I. Gonzalez (2009). Commuting and Well-being. In Y. Amichai-Hamburger (Ed.), Technology and Psychological Well-Being (pp. 174-205). Cambridge University Press, Cambridge, U.K.

Rapino, M.A. (2008). “Gender Roles and Spatial Entrapment. Proquest 2008.

Rietveld, P., Zwart, B., van Wee, B. and T. van der Hoorn (1999). "On the relationship between travel time and travel distance of commuters,” The Annals of Regional Science 33, 269-287. 
Roberts, J., R. Hodgson and P. Dolan (2011). "It's driving her mad: Gender differences in the effects of commuting on psychological health,” Journal of Health Economics 30, 1064-1076.

Robinson, J.P. (1985). "The validity and reliability of diaries versus alternative time use measures," in Time, goods, and well-being: Juster and Stafford (eds). Ann Arbor, MI: The University of Michigan, pp. 22-62.

Ross, S.L. and Y. Zenou (2006). "Are Shirking and Leisure Substitutable? An Empirical Test of Efficiency Wages Based on Urban Economic Theory,” Economics Working Papers 200621.

Sánchez de Madariaga, I. (2013). The Mobility of Care: A New Concept in Urban Transportation. In Sánched de Madariaga and Roberts (Eds.), Fair Share Cities: The Impact of of Gender Planning in Europe. London, Ashgate.

Sandow, E. and K. Westin (2010). "The persevering commuter-Duration of long-distance commuting,” Transportation Research Part A: Policy and Practice, 44(6), 433-445.

Schulz, D. and S. Gilbert (1996). "Women and transiting security: A new look at an old issue," Proceedings of the Women's Travel Issues Second National Conference, October 25-27, Baltimore.

Vanderminssen, M., Thériault, M. and P. Villenueve (2006). Work trips: Are there still gender differences? The case of Quebec metropolitan area. Paper at the Transportation Reseacr Board annual conference, Washington DC.

Van Ommeren, J.N. and J.W. van der Straaten (2008). "The effect of search imperfections on commuting behavior: Evidence from employed and self-employed workers," Regional Science and Urban Economics 38, 127-147.

Vella, F. (1994). "Gender roles and human capital investment: The relationship between traditional attitudes and female labour market performance,” Economica 61, 191-211.

Weichselbaumer, D., and R. Winter-Ebmer (2005). "A meta-analysis of the international gender wage gap,” Journal of Economic Surveys 19, 479-511.

Wheatley, D. (2013). "Location, vocation, location? Spatial entrapment among women in dual career households,” Gender, Work and Organization 20, 720-736.

White, M.J. (1986). Sex differences in urban commuting patterns, The American Economic Review 368-372.

Zax, J.S. (1991). "Compensation for commutes in labor and housing markets," Journal of Urban Economics 30, 192-207. 
Figure 1. Commuting times and sex ratios
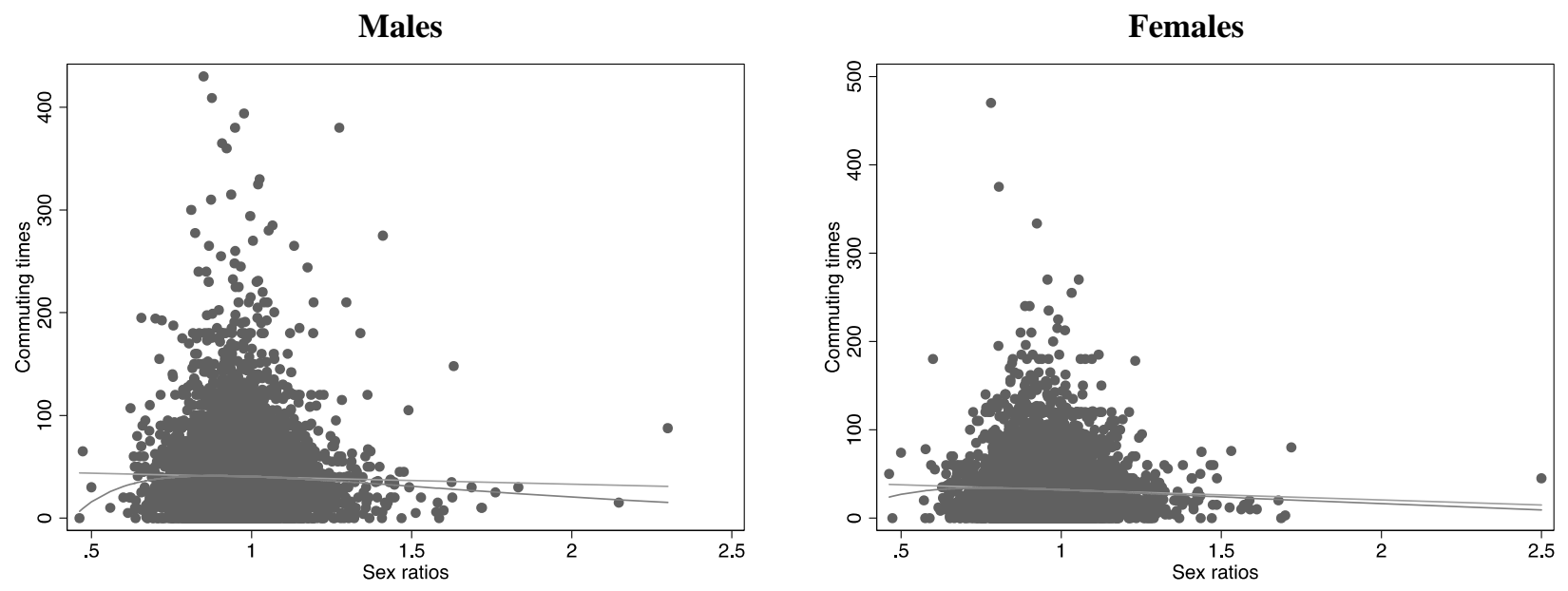

Note: The sample (ATUS 03-14) is restricted to male (panel A) and female (panel B) employed individuals who devote at least 60 minutes to work and whose information about the mode of transport is available. Commuting times are measured in minutes. Both linear and polynomial trends show an average negative relationship between sex ratios and commuting times. 
Table 1. Sum stats of variables

\begin{tabular}{|c|c|c|c|c|c|}
\hline & \multicolumn{2}{|c|}{ Male } & \multicolumn{2}{|c|}{ Female } & \multirow[b]{2}{*}{$p$-value } \\
\hline VARIABLES & Mean & S.D. & Mean & S.D. & \\
\hline Commuting time & 48.335 & 45.123 & 38.609 & 35.323 & $(<0.001)$ \\
\hline Sex ratio & 0.955 & 0.091 & 0.954 & 0.090 & $(0.144)$ \\
\hline Primary ed. & 0.083 & 0.275 & 0.061 & 0.239 & $(<0.001)$ \\
\hline Secondary ed. & 0.280 & 0.449 & 0.264 & 0.440 & $(<0.001)$ \\
\hline University ed. & 0.636 & 0.481 & 0.674 & 0.468 & $(<0.001)$ \\
\hline Living in couple & 0.675 & 0.468 & 0.554 & 0.497 & $(<0.001)$ \\
\hline Couple's status & 0.458 & 0.498 & 0.474 & 0.499 & $(<0.001)$ \\
\hline Being White & 0.847 & 0.360 & 0.797 & 0.402 & $(<0.001)$ \\
\hline Being American & 0.818 & 0.386 & 0.852 & 0.354 & $(<0.001)$ \\
\hline N. of children & 1.016 & 1.175 & 0.947 & 1.091 & $(0.002)$ \\
\hline Weekly work. hours & 45.935 & 11.900 & 39.434 & 11.203 & $(<0.001)$ \\
\hline Income level & 64337.05 & 44605.87 & 57945.41 & 43024.01 & $(<0.001)$ \\
\hline MSA size & 3.620 & 2.536 & 3.583 & 2.529 & $(0.115)$ \\
\hline N. Observations & \multicolumn{2}{|c|}{19,517} & \multicolumn{2}{|c|}{17,742} & \\
\hline
\end{tabular}

Note: The sample (ATUS 0314) is restricted to employed individuals who devote at least 60 minutes to work, and whose mode of transport is available. Commuting times are measured in minutes, income level in US\$ and number of weekly working hours in hours. Kruskal-Wallis $p$-values for the differences in parentheses (robust with $\chi^{2}$-test and $t$-test $p$-values). 
Table 2. OLS estimates for employed individuals

\begin{tabular}{|c|c|c|c|c|c|c|}
\hline & (1) & (2) & (3) & (4) & (5) & (6) \\
\hline & & Male & & & Female & \\
\hline VARIABLES & $\begin{array}{l}\text { Private } \\
\text { vehicle }\end{array}$ & Active & $\begin{array}{c}\text { Public } \\
\text { transport }\end{array}$ & $\begin{array}{l}\text { Private } \\
\text { vehicle }\end{array}$ & Active & $\begin{array}{c}\text { Public } \\
\text { transport }\end{array}$ \\
\hline Log(sex ratio) & $\begin{array}{c}-0.507 * * * \\
(0.181)\end{array}$ & $\begin{array}{c}-0.526 \\
(0.800)\end{array}$ & $\begin{array}{c}-0.281 \\
(0.588)\end{array}$ & $\begin{array}{c}-0.595 * * * \\
(0.193)\end{array}$ & $\begin{array}{c}-1.394 \\
(0.854)\end{array}$ & $\begin{array}{c}-0.239 \\
(0.447)\end{array}$ \\
\hline Secondary ed. & $\begin{array}{c}-0.027 \\
(0.021)\end{array}$ & $\begin{array}{c}0.045 \\
(0.141)\end{array}$ & $\begin{array}{c}0.044 \\
(0.125)\end{array}$ & $\begin{array}{l}-0.037 \\
(0.037)\end{array}$ & $\begin{array}{l}-0.197 \\
(0.128)\end{array}$ & $\begin{array}{c}-0.101 \\
(0.092)\end{array}$ \\
\hline University ed. & $\begin{array}{l}0.049 * \\
(0.026)\end{array}$ & $\begin{array}{c}0.109 \\
(0.154)\end{array}$ & $\begin{array}{c}-0.025 \\
(0.126)\end{array}$ & $\begin{array}{c}0.037 \\
(0.043)\end{array}$ & $\begin{array}{c}-0.014 \\
(0.118)\end{array}$ & $\begin{array}{c}-0.070 \\
(0.126)\end{array}$ \\
\hline Living in couple & $\begin{array}{c}0.127 * * * \\
(0.019)\end{array}$ & $\begin{array}{c}0.079 \\
(0.092)\end{array}$ & $\begin{array}{c}0.192 * * \\
(0.075)\end{array}$ & $\begin{array}{c}0.016 \\
(0.030)\end{array}$ & $\begin{array}{c}0.071 \\
(0.175)\end{array}$ & $\begin{array}{c}0.234^{* *} \\
(0.114)\end{array}$ \\
\hline Couple's active status & $\begin{array}{c}-0.089 * * * \\
(0.015)\end{array}$ & $\begin{array}{c}0.018 \\
(0.072)\end{array}$ & $\begin{array}{c}-0.092 \\
(0.075)\end{array}$ & $\begin{array}{c}-0.042^{* * *} \\
(0.016)\end{array}$ & $\begin{array}{c}-0.097 \\
(0.193)\end{array}$ & $\begin{array}{c}-0.075 \\
(0.095)\end{array}$ \\
\hline N. of children & $\begin{array}{c}0.005 \\
(0.006)\end{array}$ & $\begin{array}{c}0.018 \\
(0.040)\end{array}$ & $\begin{array}{l}0.060 * \\
(0.032)\end{array}$ & $\begin{array}{c}-0.064 * * * \\
(0.008)\end{array}$ & $\begin{array}{l}-0.055 \\
(0.056)\end{array}$ & $\begin{array}{l}-0.031 \\
(0.028)\end{array}$ \\
\hline Weekly work. hours & $\begin{array}{c}0.001 * * \\
(0.001)\end{array}$ & $\begin{array}{c}-0.006 * * \\
(0.003)\end{array}$ & $\begin{array}{l}-0.002 \\
(0.003)\end{array}$ & $\begin{array}{c}0.004 * * * \\
(0.001)\end{array}$ & $\begin{array}{l}-0.002 \\
(0.004)\end{array}$ & $\begin{array}{c}0.007 \\
(0.004)\end{array}$ \\
\hline Income level & $\begin{array}{c}0.000^{* * *} * \\
(0.000)\end{array}$ & $\begin{array}{c}0.000 * * \\
(0.000)\end{array}$ & $\begin{array}{c}0.000 \\
(0.000)\end{array}$ & $\begin{array}{c}0.000^{* * *} \\
(0.000)\end{array}$ & $\begin{array}{l}0.000^{*} \\
(0.000)\end{array}$ & $\begin{array}{c}-0.000 \\
(0.000)\end{array}$ \\
\hline Being white & $\begin{array}{c}-0.016 \\
(0.022)\end{array}$ & $\begin{array}{c}-0.316^{* * *} \\
(0.076)\end{array}$ & $\begin{array}{c}-0.034 \\
(0.106)\end{array}$ & $\begin{array}{c}-0.079 * * * \\
(0.022)\end{array}$ & $\begin{array}{c}-0.258 * * \\
(0.106)\end{array}$ & $\begin{array}{l}-0.010 \\
(0.078)\end{array}$ \\
\hline Being American & $\begin{array}{c}-0.200^{* * *} \\
(0.023)\end{array}$ & $\begin{array}{c}-0.352 * * * \\
(0.068)\end{array}$ & $\begin{array}{c}-0.178 * * * \\
(0.057)\end{array}$ & $\begin{array}{c}-0.193^{* * *} \\
(0.020)\end{array}$ & $\begin{array}{c}-0.310^{* * *} \\
(0.105)\end{array}$ & $\begin{array}{c}-0.104 * * * \\
(0.035)\end{array}$ \\
\hline Industry F.E. & Yes & Yes & Yes & Yes & Yes & Yes \\
\hline Occupation F.E. & Yes & Yes & Yes & Yes & Yes & Yes \\
\hline Year F.E. & Yes & Yes & Yes & Yes & Yes & Yes \\
\hline Constant & $\begin{array}{c}3.610 * * * \\
(0.151)\end{array}$ & $\begin{array}{c}4.143^{* * *} \\
(0.550)\end{array}$ & $\begin{array}{c}4.542^{* * *} \\
(0.555)\end{array}$ & $\begin{array}{c}3.848 * * * \\
(0.153)\end{array}$ & $\begin{array}{c}3.985^{* * * *} \\
(1.097)\end{array}$ & $\begin{array}{c}4.902 * * * \\
(0.501)\end{array}$ \\
\hline Observations & 18,489 & 1,338 & 736 & 16,852 & 1,167 & 788 \\
\hline R-squared & 0.059 & 0.147 & 0.142 & 0.046 & 0.120 & 0.109 \\
\hline
\end{tabular}

Note: Clustered standard errors in parentheses. The sample (ATUS 2003-2014) is restricted to employed individuals who devote at least 60 minutes to work, by gender and by mode of transport. "Commuting time" is measured in minutes and we include its logarithm. Reference category for educational level is "basic education". * Significant at the $90 \%$ level. ** Significant at the $95 \%$ level. *** Significant at the $99 \%$ level. 
Table 3. OLS estimates for private vehicle commuters, by kind of employment

\begin{tabular}{|c|c|c|c|c|c|c|}
\hline & (1) & (2) & (3) & (4) & (5) & (6) \\
\hline & & Male & & & Female & \\
\hline VARIABLES & $\begin{array}{l}\text { Private } \\
\text { sector }\end{array}$ & $\begin{array}{l}\text { Public } \\
\text { sector }\end{array}$ & $\begin{array}{c}\text { Self- } \\
\text { employed }\end{array}$ & $\begin{array}{l}\text { Private } \\
\text { sector }\end{array}$ & $\begin{array}{l}\text { Public } \\
\text { sector }\end{array}$ & $\begin{array}{c}\text { Self- } \\
\text { employed }\end{array}$ \\
\hline Log(sex ratio) & $\begin{array}{c}-0.629 * * * \\
(0.196)\end{array}$ & $\begin{array}{c}-0.833 * * * \\
(0.263)\end{array}$ & $\begin{array}{c}0.099 \\
(0.409)\end{array}$ & $\begin{array}{c}-0.602 * * * \\
(0.202)\end{array}$ & $\begin{array}{c}-0.967 * * * \\
(0.266)\end{array}$ & $\begin{array}{l}-0.202 \\
(0.549)\end{array}$ \\
\hline Secondary ed. & $\begin{array}{c}0.017 \\
(0.024)\end{array}$ & $\begin{array}{c}-0.197 \\
(0.167)\end{array}$ & $\begin{array}{c}-0.227 * * * \\
(0.076)\end{array}$ & $\begin{array}{l}-0.021 \\
(0.037)\end{array}$ & $\begin{array}{c}-0.222 \\
(0.186)\end{array}$ & $\begin{array}{c}0.181 \\
(0.148)\end{array}$ \\
\hline University ed. & $\begin{array}{c}0.083^{* * *} \\
(0.029)\end{array}$ & $\begin{array}{c}-0.038 \\
(0.149)\end{array}$ & $\begin{array}{c}-0.163 * \\
(0.086)\end{array}$ & $\begin{array}{c}0.049 \\
(0.049)\end{array}$ & $\begin{array}{c}-0.084 \\
(0.167)\end{array}$ & $\begin{array}{c}0.139 \\
(0.113)\end{array}$ \\
\hline Living in couple & $\begin{array}{c}0.136^{* * *} \\
(0.022)\end{array}$ & $\begin{array}{c}0.124 * * * \\
(0.046)\end{array}$ & $\begin{array}{c}0.146 * * \\
(0.072)\end{array}$ & $\begin{array}{c}0.049 * \\
(0.027)\end{array}$ & $\begin{array}{c}-0.044 \\
(0.084)\end{array}$ & $\begin{array}{l}-0.160 \\
(0.122)\end{array}$ \\
\hline Couple's active status & $\begin{array}{c}-0.078 * * * \\
(0.020)\end{array}$ & $\begin{array}{c}-0.121 * * * \\
(0.037)\end{array}$ & $\begin{array}{c}-0.118 * * \\
(0.054)\end{array}$ & $\begin{array}{c}-0.058 * * * \\
(0.022)\end{array}$ & $\begin{array}{c}0.020 \\
(0.054)\end{array}$ & $\begin{array}{c}0.043 \\
(0.108)\end{array}$ \\
\hline N. of children & $\begin{array}{c}0.006 \\
(0.007)\end{array}$ & $\begin{array}{l}-0.017 \\
(0.019)\end{array}$ & $\begin{array}{c}-0.001 \\
(0.019)\end{array}$ & $\begin{array}{c}-0.054^{* * *} \\
(0.008)\end{array}$ & $\begin{array}{c}-0.120 * * * \\
(0.015)\end{array}$ & $\begin{array}{l}-0.026 \\
(0.027)\end{array}$ \\
\hline Weekly work. hours & $\begin{array}{c}0.001^{* *} \\
(0.001)\end{array}$ & $\begin{array}{c}0.004^{* *} \\
(0.002)\end{array}$ & $\begin{array}{c}0.001 \\
(0.001)\end{array}$ & $\begin{array}{c}0.005^{* * *} \\
(0.001)\end{array}$ & $\begin{array}{c}0.007 * * * \\
(0.001)\end{array}$ & $\begin{array}{c}-0.004^{* *} \\
(0.002)\end{array}$ \\
\hline Income level & $\begin{array}{c}0.000 * * * \\
(0.000)\end{array}$ & $\begin{array}{c}0.000 * * * \\
(0.000)\end{array}$ & $\begin{array}{c}0.000 \\
(0.000)\end{array}$ & $\begin{array}{c}0.000^{* * *} \\
(0.000)\end{array}$ & $\begin{array}{c}0.000^{* * *} \\
(0.000)\end{array}$ & $\begin{array}{c}0.000 \\
(0.000)\end{array}$ \\
\hline Being white & $\begin{array}{c}0.009 \\
(0.022)\end{array}$ & $\begin{array}{c}-0.090 * * \\
(0.040)\end{array}$ & $\begin{array}{c}-0.087 \\
(0.072)\end{array}$ & $\begin{array}{c}-0.061 * * \\
(0.024)\end{array}$ & $\begin{array}{c}-0.126 * * * \\
(0.038)\end{array}$ & $\begin{array}{l}-0.065 \\
(0.070)\end{array}$ \\
\hline Being American & $\begin{array}{c}-0.175^{* * *} \\
(0.024)\end{array}$ & $\begin{array}{c}-0.268 * * * \\
(0.049)\end{array}$ & $\begin{array}{c}-0.256 * * * \\
(0.053)\end{array}$ & $\begin{array}{c}-0.169 * * * \\
(0.023)\end{array}$ & $\begin{array}{c}-0.278 * * * \\
(0.043)\end{array}$ & $\begin{array}{c}-0.214^{* * *} \\
(0.062)\end{array}$ \\
\hline Industry F.E. & Yes & Yes & Yes & Yes & Yes & Yes \\
\hline Occupation F.E. & Yes & Yes & Yes & Yes & Yes & Yes \\
\hline Year F.E. & Yes & Yes & Yes & Yes & Yes & Yes \\
\hline Constant & $\begin{array}{c}3.696 * * * \\
(0.157)\end{array}$ & $\begin{array}{c}4.115^{* * *} \\
(0.578)\end{array}$ & $\begin{array}{c}3.688 * * * \\
(0.338)\end{array}$ & $\begin{array}{c}3.788 * * * \\
(0.211)\end{array}$ & $\begin{array}{c}4.515^{* * *} \\
(0.497)\end{array}$ & $\begin{array}{c}3.784 * * * \\
(0.525)\end{array}$ \\
\hline Observations & 13,793 & 2,441 & 2,255 & 12,538 & 3,299 & 1,015 \\
\hline R-squared & 0.074 & 0.078 & 0.074 & 0.049 & 0.110 & 0.089 \\
\hline
\end{tabular}

Note: Clustered standard errors in parentheses. The sample (ATUS 2003-2014) is restricted to male and female private sector, public sector, and self-employed individuals who devote at least 60 minutes to work, respectively. "Commuting time" is measured in minutes and we include its logarithm. Reference category for educational level is "basic education". * Significant at the 90\% level. ** Significant at the 95\% level. $* * *$ Significant at the $99 \%$ level. 


\section{Appendix}

Table A1. Placebo tests

\begin{tabular}{|c|c|c|c|c|c|c|}
\hline & (1) & (2) & (3) & (4) & (5) & (6) \\
\hline & Male & Female & \multicolumn{2}{|c|}{ Male } & \multicolumn{2}{|c|}{ Female } \\
\hline VARIABLES & $\begin{array}{l}\text { Private } \\
\text { vehicle }\end{array}$ & $\begin{array}{l}\text { Private } \\
\text { vehicle }\end{array}$ & $\begin{array}{l}\text { Private } \\
\text { sector }\end{array}$ & $\begin{array}{l}\text { Public } \\
\text { sector }\end{array}$ & $\begin{array}{l}\text { Private } \\
\text { sector }\end{array}$ & $\begin{array}{l}\text { Public } \\
\text { sector }\end{array}$ \\
\hline Log(sex ratio) & $\begin{array}{c}0.127 \\
(0.118)\end{array}$ & $\begin{array}{c}0.172 \\
(0.206)\end{array}$ & $\begin{array}{c}0.219 \\
(0.148)\end{array}$ & $\begin{array}{c}0.179 \\
(0.387)\end{array}$ & $\begin{array}{c}0.153 \\
(0.260)\end{array}$ & $\begin{array}{l}-0.101 \\
(0.343)\end{array}$ \\
\hline Secondary ed. & $\begin{array}{l}-0.028 \\
(0.023)\end{array}$ & $\begin{array}{l}-0.043 \\
(0.035)\end{array}$ & $\begin{array}{c}0.018 \\
(0.025)\end{array}$ & $\begin{array}{l}-0.207 \\
(0.176)\end{array}$ & $\begin{array}{l}-0.023 \\
(0.038)\end{array}$ & $\begin{array}{l}-0.281^{*} \\
(0.168)\end{array}$ \\
\hline University ed. & $\begin{array}{l}0.048^{*} \\
(0.028)\end{array}$ & $\begin{array}{c}0.030 \\
(0.043)\end{array}$ & $\begin{array}{c}0.083^{* * *} \\
(0.031)\end{array}$ & $\begin{array}{l}-0.032 \\
(0.155)\end{array}$ & $\begin{array}{c}0.048 \\
(0.051)\end{array}$ & $\begin{array}{c}-0.149 \\
(0.145)\end{array}$ \\
\hline Living in couple & $\begin{array}{c}0.133^{* * *} * \\
(0.020)\end{array}$ & $\begin{array}{c}0.035 \\
(0.031)\end{array}$ & $\begin{array}{c}0.144^{* * *} \\
(0.023)\end{array}$ & $\begin{array}{c}0.128 * * * \\
(0.044)\end{array}$ & $\begin{array}{l}0.065^{* *} \\
(0.027)\end{array}$ & $\begin{array}{l}-0.017 \\
(0.084)\end{array}$ \\
\hline Couple's active status & $\begin{array}{c}-0.089 * * * \\
(0.015)\end{array}$ & $\begin{array}{c}-0.054^{* * *} \\
(0.016)\end{array}$ & $\begin{array}{c}-0.076^{* * *} \\
(0.019)\end{array}$ & $\begin{array}{c}-0.127 * * * \\
(0.038)\end{array}$ & $\begin{array}{c}-0.065 * * * \\
(0.021)\end{array}$ & $\begin{array}{c}0.002 \\
(0.058)\end{array}$ \\
\hline N. of children & $\begin{array}{c}0.001 \\
(0.006)\end{array}$ & $\begin{array}{c}-0.065^{* * *} \\
(0.008)\end{array}$ & $\begin{array}{c}0.001 \\
(0.007)\end{array}$ & $\begin{array}{l}-0.021 \\
(0.018)\end{array}$ & $\begin{array}{c}-0.055 * * * \\
(0.008)\end{array}$ & $\begin{array}{c}-0.127 * * * \\
(0.014)\end{array}$ \\
\hline Weekly work. hours & $\begin{array}{c}0.001^{* *} \\
(0.001)\end{array}$ & $\begin{array}{c}0.004^{* * *} \\
(0.001)\end{array}$ & $\begin{array}{c}0.002^{* * *} \\
(0.001)\end{array}$ & $\begin{array}{c}0.004^{* *} \\
(0.002)\end{array}$ & $\begin{array}{c}0.005^{* * *} \\
(0.001)\end{array}$ & $\begin{array}{c}0.006^{* * *} \\
(0.001)\end{array}$ \\
\hline Income level & $\begin{array}{c}0.000 * * * \\
(0.000)\end{array}$ & $\begin{array}{c}0.000^{* * *} \\
(0.000)\end{array}$ & $\begin{array}{c}0.000^{* * *} \\
(0.000)\end{array}$ & $\begin{array}{c}0.000^{* * *} \\
(0.000)\end{array}$ & $\begin{array}{c}0.000^{* * *} \\
(0.000)\end{array}$ & $\begin{array}{c}0.000^{* * *} \\
(0.000)\end{array}$ \\
\hline Being white & $\begin{array}{l}-0.017 \\
(0.023)\end{array}$ & $\begin{array}{c}-0.083 * * * \\
(0.023)\end{array}$ & $\begin{array}{c}0.005 \\
(0.023)\end{array}$ & $\begin{array}{c}-0.093^{* *} \\
(0.043)\end{array}$ & $\begin{array}{c}-0.070 * * * \\
(0.026)\end{array}$ & $\begin{array}{c}-0.116 * * * \\
(0.037)\end{array}$ \\
\hline Being American & $\begin{array}{c}-0.198 * * * \\
(0.022)\end{array}$ & $\begin{array}{c}-0.191 * * * \\
(0.020)\end{array}$ & $\begin{array}{c}-0.176^{* * *} \\
(0.024)\end{array}$ & $\begin{array}{c}-0.235^{* * *} \\
(0.048)\end{array}$ & $\begin{array}{c}-0.171 * * * \\
(0.023)\end{array}$ & $\begin{array}{c}-0.252 * * * \\
(0.043)\end{array}$ \\
\hline Industry F.E. & Yes & Yes & Yes & Yes & Yes & Yes \\
\hline Occupation F.E. & Yes & Yes & Yes & Yes & Yes & Yes \\
\hline Year F.E. & Yes & Yes & Yes & Yes & Yes & Yes \\
\hline Constant & $\begin{array}{c}3.182 * * * \\
(0.120)\end{array}$ & $\begin{array}{c}3.338 * * * \\
(0.201)\end{array}$ & $\begin{array}{c}3.112 * * * \\
(0.134)\end{array}$ & $\begin{array}{c}3.354^{* * *} \\
(0.465)\end{array}$ & $\begin{array}{c}3.264 * * * \\
(0.278)\end{array}$ & $\begin{array}{c}4.320 * * * \\
(0.411)\end{array}$ \\
\hline Observations & 17,798 & 16,253 & 13,270 & 2,351 & 12,093 & 3,177 \\
\hline R-squared & 0.059 & 0.045 & 0.074 & 0.074 & 0.048 & 0.106 \\
\hline
\end{tabular}

Note: Clustered standard errors in parentheses. The sample (ATUS 2003-2014) is restricted to employed individuals, by gender, who devote at least 60 minutes to work (Columns 1 and 2), and to private sector employees, by gender, who commute by private vehicle or by public transport (Columns 3-6). "Commuting time" is measured in minutes and we include its logarithm. Reference category for educational level is "basic education”. Sex ratios have been randomly matched, controlling for different states of residence. * Significant at the $90 \%$ level. ** Significant at the $95 \%$ level. *** Significant at the $99 \%$ level. 